\title{
The significance of work allocation in the professional apprenticeship of solicitors
}

\author{
Jane Ching
}

Nottingham Law School, Nottingham Trent University, Nottingham, UK

Email: jane.ching@ntu.ac.uk

(Received February 2011; final version received

It is a peculiarity of the solicitors' profession that it has historically relied on methods of pre-qualification "training" by way of apprenticeship and that an entirely respectable non-graduate route into the profession remains. In a political context, however, where the profession is called upon positively to demonstrate its standards of performance, the professional regulator seeks to attach a competence framework to the existing model; shifting the focus from how the trainee learns to what the trainee learns. This paper will explore the period of traineeship from the perspective of the trainees themselves, drawing on two small qualitative studies, focussing on the fundamental context factor (Eraut et al, 2002) of the allocation and structuring of their work. In the first study the context for this evaluation is the set of outcomes being tested by the professional regulator and in the second, the perceptions of qualified individuals looking back at their apprenticeship,

The paper concludes that there remains work for the profession to do not only in fostering supportive and expansive apprenticeships, but in attending, however, supportive the surrounding environment, to the work being carried out by trainees and its relationship with the work carried out by newly qualified solicitors.

Keywords: apprenticeship; solicitors; work-based learning; learning factors; learning context; legitimate peripheral participation 


\section{Introduction}

It is a peculiarity of the solicitors' profession that it continues to rely on methods of pre-qualification "training" by way of apprenticeship to the extent that an entirely respectable non-graduate route (which was, until the growth of university entrance in the 1960s, the majority route (Burrage, 1996)), for Fellows of the Institute of Legal Executives, remains. Of all those qualifying in England and Wales in 2008-2009, 1.7\% did so by this route (Law Society, 2009). Those non-graduates are required to have at least five years' experience in practice and are exempted from the two-year "training contract" (previously "articles", Solicitors Regulation Authority 2000, 2008) required of their graduate colleagues. The concept of apprenticeship remains, therefore, embedded, at least at present (see suggestions that a broad-based period of apprenticeship is unnecessary in Hunt, 2009). What is new, however, is the proposal by the profession's regulator, to substitute a common "period of workbased learning" for the training contract, a period summatively assessed by reference to a range of pre-determined outcomes at a common standard across the profession ("the work-based learning project"). This necessarily, as I discuss below, assumes some commonality in the kind of work that trainees will need to be doing in order to achieve those outcomes.

This article considers the adequacy of the "kind of work" as preparation for practice at the point of qualification. In doing so it builds on the identification of "allocation and structuring of work" as one of a triad of critical context factors in early career learning in the LiNEA study of novice nurses, engineers 
and accountants (Eraut et al, 2002; Maillardet et al, 2002; Miller and Blackman,

2002). ${ }^{1}$ In the LiNeA project, the "allocation and structuring of work" was

\begin{abstract}
central to our participants' progress, because it affected 1 the difficulty or challenge of the work, 2 the extent to which it was individual or collaborative and 3 the opportunities for meeting, observing and working alongside people who had more or different expertise and for forming relationships that might provide feedback and support. For novice professionals to make good progress. a significant proportion of their work needed to be sufficiently new to challenge them without being so daunting as to reduce their confidence.

( Eraut et al, undated:14).
\end{abstract}

The context factors support important learning factors identified (Eraut et al, ibid) as: challenge and value of the work; feedback and support; personal agency; confidence and commitment. The analysis of the data in this paper considers allocation and structuring of work in two respects:: first, measured against the assumptions inherent in the pre-determined list of outcomes of the work-based learning project; second, the perceptions of the apprentices themselves as to the contribution of the kind of work they did as trainees to preparing them for "full participation" in legal practice. By way of introduction, however, it is instructive to consider the evolution of the professional apprenticeship for solicitors in England and Wales to this point at which the regulator feels it necessary to propose a common set of outcomes.

\title{
From kinship to standards: apprenticeship and its evolution in the solicitors' profession
}

Eraut usefully defines "apprenticeship" in origin as a system whereby

"[t]he young apprentice ... received training over a period of time in return
for contributing to his employer's business, a contribution which increased in

\footnotetext{
${ }^{1}$ The other context factors were encounters and relationships with people at work and individual participation and expectations of performance and progress.
} 
value as the quality of his work improved and he became able to take on more complex tasks and greater responsibility. The mutual interests of the master/employer and the apprentice were protected by a legal contract and socially sanctioned by the guild to which the master belonged".

Eraut (2004:45)

This model emerged from the medieval craft guilds, which once housed the common lawyers and scriveners who, in the mid-1700s, became the solicitors' profession. As Burrage (1996) points out, the self-declared role of the profession at this time and until the mid-twentieth century was to preserve (or, I suggest, as an aspirant profession, to establish) its own "honour, reputation and status". In the case of solicitors, Burrage (ibid,: 55) suggests that this meant "withdrawing to an honourable work jurisdiction" and discarding low status work or work of suspect integrity as well as taking, and retaining, control over access to the profession: the necessary apprenticeship. This control, I suggest, has two aspects: a) control over access to the corpus of professional knowledge, skills and work and b) control over the values and cohesion of the members of the profession as a group.

Larson, certainly, sees the control by professions generally of access to their membership from the $19^{\text {th }}$ century as a means not only of defining but also of controlling the market for the professions' services (later writers such as Marshall (2004) have more recently detected lawyers working to create a market for their services). Larson argues that the hold of the [law] firm on the label of professionalism is tied to control over the "commodity" of the corpus of professional knowledge and skills, suggesting that

the standardisation allowed by a common or clearly defined basis of training is far more important for the unification of a profession than the more diffuse subcultural aspects, which are often underscored as major aspects of the socialisation process and arbitrarily distinguished from the cognitive and technical basis. This basis defines the common language and the tacit knowledge that distinguish a 
profession as a whole from the laity. It is in fact the main support of a professional sub-culture

Op. Cit: 45

The initial model of solicitors' apprenticeship, jealously guarded by the profession to the extent of largely successfully being kept away from the academy until the 1960s, was based on kinship, additionally intended to inculcate in the apprentice, who might be the solicitor's son or a close connection of his family, the second aspect of control: the values of the profession. Articles were a form

of moral training, of initiation into networks that linked every past and present member of the profession, by ties of obligation, loyalty and possibly affection, that enabled the newcomer to belong, to empathize with its aspirations and concerns and to share its sense of honour.

(Burrage, op. cit:54).

It is also possible to infer, I suggest, that the apprentice need also serve his masters in a postulant role for a period as a personal price of entry to the profession, which is not inconsistent with the fact that, within living memory, a "premium" was still paid to the principal for the privilege of articles. Acquisition of a corpus of professional knowledge and skills in the first two centuries of the profession might, then, be subservient to the acquisition of values and acculturation:

critics of the professions repeatedly poured scorn on articles ... and always found ample evidence to show that they were haphazard, slapdash and inefficient methods of transmitting legal knowledge. Articles usually involved vast amounts of tedious, routine tasks, years of drudgery, during which the clerk might incidentally pick up scraps of legal knowledge

(Burrage, op. cit.53), 
Burrage suggests (op.cit: 68 ) that the increase of access to university degrees in law in the 1960 s, producing a more diverse and less humble group of apprentices; together with the rise in number of other providers of legal services and, significantly, increased external scrutiny and demands for accountability, has contributed to a change from this kinship model which was able to prioritise membership and clubbability over measurable knowledge and skills. As noted by Galanter and Roberts (2008) after the second world war, articled clerks were recruited on the basis of their qualifications (gained in the academy) rather than their personal connections. At the same time, the role of "assistant solicitor"; not a trainee, but not (yet) a partner, entered the picture. In addition, from the 1990s, entrants to the profession no longer expected to be "made up to" partner automatically but to have to compete for that status. It is common to hear from assistant solicitors today that, whilst they may have aspirations to expertise in their area of practice, they have no aspirations to that partnership status which might previously have marked full membership of the profession and full entry to the club.

Larson (op.cit.) suggests that the professions as a group have moved over time to an "ideological" approach to the concept of professionalism, which continues to justify inequality of status and closure of access to the club despite a changed marketplace. Such an argument would suggest that the price of a solicitor's services is justified by the length of time taken to acquire that status and not by any guarantee of increased quality in those services as a result of the years of training. Nevertheless, guarantees of standard of service based on knowledge and skills are now being explicitly sought. Burrage identifies an onslaught of reduction in monopolies, increased external scrutiny and regulation 
and opening of the legal services sector as early as the 1960s, but particularly evident during the Thatcher government of the 1980 s as challenging the "collective status strategy" (op cit: 68) of the solicitors' profession. Evetts describes the "more traditional, historical form" of professionalism she describes as "occupational professionalism", "controlled by practitioners themselves and ... based on shared education and training, a strong socialisation process, work culture and occupational identity ..." (2006a:141). She distinguishes this from a discourse of "organisational professionalism". This latter trend serves to emphasise the move towards external accountability and discipline; less self-regulation by a profession than regulation both of market and of practice standards, from without. "Trust is to be replaced by accountability, but accountability seems to result in the standardization of work practices" (Evetts, 2006b: 525). As Fournier (1999) notes, the trend is to treat "professionalism" as a metaphor for acountability and discipline. It might be argued that the very concept of applying common outcomes inherent in the work-based learning project is an emanation of such standardisation. There is, however, an element of play in the articulatoin of the outcomes. Faulconbridge and Muzio, however, detect, in a study of partners in multinational law firms, a form of "organisational localisation" where, although there might be "global 'inductions' or 'conferences' for newly recruited trainees/associates, the training and development of lawyers is otherwise decentralized to the office and even individual professional level" (2008: 19). In such a model,

the traditional values, objectives and rewards connected with professionalization projects are increasingly achieved and secured through the support of appropriate organizational systems, structures and procedures. Yet ... these organizational tactics and mechanisms are ultimately defined and influenced by professional interests (op. cit: 20 ). 
Whilst, I suggest, there is sufficient play in the proposed work-based leanring outcomes to permit a degree of integration into existing systems, the question of external accountability and the need for explicit organizational systems remains significant. The solicitors' profession's remaining monopolies, standards and educational structure are, at present, under question both from the inside (Law Society 2001, 2003, 2005; SRA 2007; Hunt 2009) and the outside (Farrar 2001; Clementi 2004; Department for Constitutional Affairs 2005). The Law Society has been obliged to divest itself of its regulatory powers to the separate Solicitor's Regulation Authority ("SRA"). In some fields of legal work, work is increasingly commoditised and, as for example with work done under what used to be called "legal aid", standardised (Sommerlad, 2007, 2008) Legal work is now carried out by legal executives; paralegals; licensed conveyancers; patent and trade mark attorneys amongst others so that trainee solicitors may be "competing" with members of other professions for learningrich work. The period to qualification for some of these other professions is no shorter and no less intensive, than for solicitors.

From 2012 when the Legal Services Act 2007 is fully implemented, the range of individuals carrying out legal services will be widened further and some solicitors will find themselves training and working within "alternative business structures" containing a mixture of legal and other professionals. In contrast to the specialist legal professions (costs lawyers; trade mark and patent attorneys; barristers), and the paralegals and legal executives who may now carry out a substantial proportion of the more process-driven tasks on which trainees once cut their teeth, the solicitors' profession has once again become aspirant: it no longer has ostensible power to define or control the market for 
legal services. It must therefore find some way to justify its continued existence (and its fees); to re-articulate its "honour, reputation and status" as a distinct profession in its own right. Clubbability and shared values alone will, I suggest, not be sufficient. It has, nevertheless, retained an apprenticeship model whereby the trainee is contracted to a master, for a defined period of time, contributing some element of work in return for "supervised experience in legal practice through which [the trainee] can refine and develop their professional skills" (SRA, 2008a: 3).

The change that is proposed by the SRA in the work-based learning project is increased monitoring of the scope of that experience and assessment of the extent of the development of professional knowledge and skills. This is to be achieved by use of a competence framework ("the work-based learning outcomes"). Prior to this, the relevant practice standards only required the trainee (passively) to "understand the need to" or "understand the importance of" (Ching, 2010) aspects of good practice. ${ }^{2}$ The work-based learning outcomes focus on application of legal knowledge and on workplace skills. There is, as I have indicated, a certain amount of play within them. They are not so specific as to refer to particular types of legal transaction; but their focus remains very much on what individuals do and can do as part of their working practice Consequently they are reliant on the trainee being allowed to participate in

\footnotetext{
${ }^{2}$ There is scope for a conflict here between the standards and the prescribed contract for trainees, which places a contractual obligation on the employer to

a) provide the trainee solicitor with the opportunity to practise:

i) client care and practice support skills;

ii) communication skills;

iii) drafting;

iv) interviewing and advising;

v) legal research;

b) provide the trainee solicitor with the opportunity to gain experience of the practice of:

i) advocacy and oral presentation skills;

ii) case and transaction management;

iii) dispute resolution;

iv) negotiation.
} 
certain kinds of activity (to have some direct contact with clients, for example), that is, on the allocation and structuring of the work they do. They contain references to more value-laden attributes such as "professionalism" and to the rules of professional conduct but they do not, I suggest, purport to delineate or test in toto the values of the profession. Still less can they delineate who will or will not be accepted by the club and to some extent, given that part of the impetus towards this outcomes-based approach is to increase access to the profession (SRA, 2008b); they might be seen as a deliberate move against clubbability. However, if acquisition of skills in workload management; communication; client relations and the like now represent the totality of the desiderata of the profession for the point of qualification; an individual transferring in from another profession might be able to demonstrate achievement of the vast majority of these outcomes with only a very limited period of apprenticeship to a lawyer. Or none at all.

If the profession is to continue to lay claim to a right to impose a predetermined period of apprenticeship, then, I suggest, it must be demonstrated to have further utility beyond achievement of a selection of knowledge and skillsbased competences that could be demonstrated at a suitable level at any time within it or even acquired outside it. There may be additional competences which, not yet articulated in the regulator's framework, can only be acquired in or demonstrated by an apprenticeship period, or it may have benefits which are too fluid or too personal to the individual; the firm or the profession as a whole, to articulate as competences in any meaningful way.

It is, I suggest, difficult to envisage the values and cohesion of the profession being easily articulated in a competence framework. Bourdieu 
argues that such "conditionings" (1990: 53) constitute the habitus, "embodied history, internalised as second nature and so forgotten as history" (op.cit: 56); "a system of dispositions common to all products of the same conditionings" (ibid.: 59, see also Colley et al, 2003)). The habitus might include, therefore, both what I have referred to as "values" and, rather more pejoratively, as "clubbability". Acquisition of the habitus may be a largely tacit process in many cases, (Monahan 2001; Colley et al., 2003), but its acquisition may in others, particularly for those entering the profession as "outsiders" from the white, middle-class norm for members of the club, be explicit and painful (Sommerlad, 2007, 2008, see also Vignaendra, 2001; Laurence Simons, 2010).

One aspect of conditioning or acquisition of an appropriate habitus which is not necessarily allied easily with "values" but is significant to allocation and structuring of the individual's work. Part of the formation of a professional identity, I suggest, involves moving from a defensive "student" attitude which may involve explicit proving of competence; seeking of guidance or deflection of criticism towards a different ethos. This different ethos may be difficult to articulate but is part of a "professional rhetoric of uncertainty" that acknowledges the limits of information and solutions (Lingard et al, 2003). Such tolerance for ambiguity in real-life situations may be marked by age (Kitchener and King, 1990) or a more advanced stage on the spectrum between novice and expert (Benner, 1984; Dreyfus, 1986). Schön (1983, 1984, 1995) perceives dealing with such "swampy" problems as concomitant not only with expertise but with professionalism in the "occupational" sense. Whilst this aspect of identity, encompassing both values and knowledge, is not exclusive to membership of the solicitors' club, it assumes, as do the SRA's work-based 
learning outcomes, a certain kind of work; one in which uncertainty and ambiguity can occur. In some training contracts, as in some post-qualification jobs, commoditisation of legal services work (Sherr, 2001; Sanderson and Sommerlad, 2002) may mean that the opportunity to engage in work which permits exploration of uncertainty is limited or absent. The nature of the work provided to a trainee is, then, a critical factor: whether it is sufficiently learningrich to expose trainees to the inherent uncertainty and ambiguity found in complex matters of practice. .

\section{The significance of the work provided: learning within the apprenticeship}

The kinship model suggests a close relationship between trainee and principal in what has been called a "person-centred" approach to apprenticeship (Nielsen and Kvale, cited in Eraut, 2004: 47). Eraut argues this to be the model assumed by Polanyi in his exploration of acquisition of tacit (unarticulated) knowledge and by Schön in his discussion of learning by reflection-in-action in the practicuum $(1983,1987,1995$, critiqued in the legal context by Neumann, 2000). Here the master works closely with the trainee, allocates his or her work, is role model and personally responsible for transmission of the knowledge, skills and values (aspects of the habitus). More frequently in the modern training contract, where the trainee solicitor rotates between different "seats" in the organisation and works with senior lawyers, peers and assistant solicitors, the apprenticeship is more "de-centred", which Eraut links to the "community of practice" paradigm developed by Lave and Wenger (1991). Whilst the community of practice concept tends to focus on the individuals involved and 
their interactions, it is in this context that Lave and Wenger identify "legitimate peripheral participation" as a description of the nature of the work carried out by the apprentice;

[a] newcomer's tasks are short and simple, the costs of errors are small, the apprentice has little responsibility for the activity as a whole. A newcomer's tasks tend to be positioned at the ends of branches of work processes, rather than in the middle of linked work segments. ...

Lave and Wenger, (ibid,: 110)

That participation is envisaged as a learning-focused (Rogers, 2003) trajectory whereby the work of the apprentice changes over time so as to move "toward more-intensive participation" (Lave and Wenger, op. cit.: 36) and through "situated learning" to create a "bridge" between more cognitive theories of learning and acquisition of expertise (see Chi et al., 1988; Benner, 1984; Dreyfus and Dreyfus, 1986; Bereiter and Scardamalia, 1993; Blasi, 1995, Tennant, 1997) and those of social practice. Effective legitimate peripheral participation would then seem to be contingent on whether the working environment comprised by both tasks ("practice") and individuals ("community") constitutes a "community of practice": "an activity system [my italics] about which participants share understandings concerning what they are doing and what that means in their lives and for their communities " (Lave and Wenger, op. cit.: 98). Much hinges on the quality of this community of practice and the concept has been criticised for, inter alia, permitting sterile reproduction of the same practices rather than responding to change (Fuller, 2007); as oversimplying the range of relationships and trajectories involved in practice (ibid.); as overlooking the fluidity of modern work groups (Engestrom, 2007) and as showing learning as it "should be" rather than as it is (Hughes, 2007). 
Further, Eraut (2004: 201) criticises Lave and Wenger as attempting "to eradicate the individual perspective on knowledge and learning and [failing] to recognise the need for an individually situated (as well as a socially situated) concept of knowledge in the complex, rapidly changing, post-modern world". From the perspective of the individual apprentice, however, Fuller and Unwin link the surrounding community of practice, where effective, to an "expansive" apprenticeship where personal development is likely to be contributed to by "the provision of opportunities to reflect on practice; the ability to envisage and experience long trajectories and careers; and opportunities to develop new identities through belonging to multiple communities of practice" (Fuller and Unwin, 2003b: 417). Fuller and Unwin's empirical work suggests that where an apprenticeship programme is unstructured and unplanned - leaving learning to chance, to osmotic and tacit learning and to observation rather than practice - "learning is much more ad hoc and haphazard and is more likely to be driven by organisational and commercial expedience" (2003a: 43). Lave and Wenger themselves provide evidence of the significance of workload allocation in such an environment in their example of trainee meat cutters (op. cit.:76) whose work was allocated on the basis of "where they can work for [the employer] most efficiently" (ibid:78) and whose physical environment prevented them from even observing more senior colleagues. This question of commercial expedience is important. It can be seen at its extreme in a "restrictive" apprenticeship model where "access to learning [is] restricted in terms of tasks/knowledge/location" (Fuller and Unwin, 2003: 411); which prioritises the apprentice's role as fee-earner, or where for commercial reasons, the apprentice is kept to a static range of mechanical tasks 
rather than moving "through a series of stages of complexity, supported by experts and allowing time for maturation both in terms of occupational expertise and personal development" (Fuller and Unwin, 2009: 410).

The concept of legitimate peripheral participation suggest, tends not only to displace the learning of and for the individual (who, after all, might change employment on qualification) but also to assume a democracy of power which may not be present and in some very fee-focused, untransparent and hierarchical law firms may very much not be present for the individual trainee. Boon and Whyte suggest, for example, that "from the views expressed to us, it appears that some employers expect trainees on day one to be consummate solicitors" (2002, 32, see also Fancourt, 2004 and Boon and Whyte, 2007): the most extreme of the "restrictive" as opposed to "expansive" models of apprenticeship. At present, whilst there are, of course, employers with highly supportive training frameworks which articulate competences, require frequent reviews and appraisal and so on, no-one is required by the profession itself to have learned anything during or at the end of the training contract. No-one (other than the pioneers involved in the work-based learning project) is externally tested to determine what, if anything, they did learn. It is possible, of course, for a strong-willed individual to overcome being over-stretched

[t]hose who remember their training with fondness, as a beneficial and worthwhile experience, tended to do so for a combination of reasons. Primary among these was being given early responsibility, being kept occupied with lots to do, and being given support and help or constructive criticism when required. ... Yet a lack of support in a trainee's work environment can have advantages; advantages that were in reality only appreciated in retrospect. For instance a number of participants who reported difficult training contracts said their experiences made them independent, self sufficient and confident. Boon and Whyte, (2002: 45) 
What it is more difficult for an individual to overcome, I suggest, is a restrictive and under-stretching environment in which, like Lave and Wenger's meat cutters, he or she is kept to routine or mechanical tasks (photocopying, note-taking, legal research). The "context factor" of "allocation and structuring of work", at present entirely within the ownership of the employer, remains critical.

\section{Research}

In this paper I draw on two small qualitative research studies, involving the structured or semi-structured interviewing of young lawyers who were, in the first place (Ching 2009a) embedded in the training contract phase and in the other (Ching 2009b) had completed it. Both adopted a broadly phenomenological methodology, focussing on individual's experiences $a s$ articulated by them.

The first (Ching 2009a) investigated the professional apprenticeship through structured interview of nine current trainee solicitors in two firms, asking each to evaluate whetherthey had the opportunity to demonstrate the series of outcomes proposed by the SRA for the period of work-based learning; that is, the extent to which the outcomes translated into the work trainees were doing. The second (Ching 2009b), an interview study of 13 individuals practising in the specific field of civil litigation, across five law firms of different types (including small, regional and City firms), was envisaged as focussing on individuals' learning from the point of qualification onwards.. In the context of this paper, however, results showing what could be described as a "deficit" in the effectiveness, in some cases, of the training contract as 
preparation for the individual's role on qualification, allowed conclusions about the nature of the work allocated during the training contract to be drawn.

\section{Findings and Discussion}

One difficulty in seeking to formalise the apprenticeship period with common standards delineating the scope of a trainee's activity ${ }^{3}$ is the diversity of the solicitors' profession.

... [T] he nature of practice is so diverse that some newly admitted solicitors might be expected to conduct a whole case, $\ldots$ while others, such as those engaged in large commercial transactions, would only ever be responsible for part of the whole. Thus, there are difficulties in specifying a common level of outcome that could be expected from all solicitors in areas such as communication skills.

Law Society (2001: 6)

... [I]t was ... observed by one respondent that minimum competencies are very different in high street and City practices and that not all solicitors need "general knowledge" even of all "key areas".

Boon and Webb, (2002: 13)

Although the framework underlying the work-based learning project seeks to address this in the breadth (arguably therefore the lack of specificity) of the outcomes, interviewees in the first study (Ching 2009a) nevertheless identified impediments to their being allocated work that might allow them to demonstrate the outcomes. This produced the following range of negative possibilities:

(1) This activity is not performed in this organisation at all.

(2) This activity is performed but not by trainees.

\footnotetext{
${ }^{3}$ There is already pressure on the larger corporate firms arising from the existing requirement simply to provide a range of experience such that the litigation experience may be provided only by way of simulation, pro bono work or both.
} 
(3) This activity is performed by trainees but with substantial filtering before the output reaches the client.

(4) This activity is performed by trainees in some seats but not in others. Three main areas were identified; involvement with the law (i.e. the need for research into legal problems); client interaction and opportunity to manage concurrent tasks.

(5) This activity is performed by trainees but it is fortuitous whether it will occur during the training contract.

(6) This activity is performed by trainees but only towards the end of the training contract/end of the seat.

(7) This activity is performed by trainees but it is difficult to provide satisfactory evidence of it (especially to a third-party assessor outside the firm).

For participants in this study, opportunities varied according to the nature of the work being done (large transactions as compared with smaller matters where the trainee might be able to work on his or her own file as lead fee-earner with suitable support); the degree to which the individual was expected or permitted to have actual contact with clients and whether or not individual supervisors allowed their trainees enough latitude to allow them to, for example, demonstrate that they could manage concurrent tasks. Mapping opportunity against seat is important if or to the extent that the competences of the period of work-based learning are assessed summatively towards the end of the period. Even this limited investigation, however, suggests that there is work to be done 
by the profession to audit the work allocated to trainees against the proposed outcomes.

The second study (Ching 2009b) looked, inter alia, at the intersection between the end of the training contract and the point of qualification. Key to this discussion is what emerged as a series of new expectations arising at the point of qualification - for example, as to time management and cost responsibility, of involvement in the whole of a case - for what the new solicitor was then expected to be able to do, but which had not necessarily been something to which the trainee had been introduced. Kelly, suggesting, inter alia, a more expansive model of apprenticeship for trainee surgeons, points out a similar difficulty: "[b]efore the era of the internal market the inpatient service was a "total" (albeit harsh) learning environment, because virtually all patients were hospitalised until they recovered completely. This allowed trainees to participate in the complete continuum of diagnosis and treatment ... In this context it becomes even more important for trainees to learn how to tap the experience of peers and mentors within the "community of practice" - and for their access and induction to be actively supported and encouraged by the more experienced members of the team".(2001: 59).

The quality of the training contract was significant both negatively

... I don't think that my training contract has really prepared me for - fully - for what I'm now doing on a daily basis.

Solicitor, 2 months PQE.

and positively: at that firm. ... I felt that [the partner] was a fantastic role model as a litigator: 
very experienced, a very good lawyer in every respect and manager. So I felt the training I had received from that firm was second to none.

Solicitor, $2 \frac{1}{2}$ years PQE.

Even where the training contract was positive for such matters as acculturation and values, a substantial step change in the kind of work that was expected still took place on qualification:

... I learned a huge amount in my training but the nature of the sort of cases that I tend to work on with the partner, [name], that I mainly work for are very complicated, huge cases, so when I first qualified I felt very, well, not very confident in some ways in terms of being able to look at a case and know, analyse it in any sort of comprehensive way.

Solicitor, 2 years PQE.

What was also important was any similarity between the work involved in the "last seat" of the training contract immediately preceding qualification and the field of practice in which the individual worked afterwards. In some cases this transition was so smooth as to make the moment of qualification something of an anti-climax:

... there was no magical transformation for me on qualification, in fact. It did feel a bit of a let-down, in fact, because I don't know what I expected would happen to break open butterfly-like and fly away, or what. There was a significant hike in salary but in terms of my knowledge or my ability to do my job I didn't feel a great change overnight.

Solicitor, 4 years PQE

To produce this effect, however, the congruence with the work done in the "last seat" had to be very close. Factors which seemed to dislodge feelings of confidence and competence on qualification included movement into a very specialised field on qualification; a change of focus from acting for claimants to acting for defendants and moving to a new firm on qualification with a concomitant disruption to working methods already learned. 
I hadn't had the experience of someone who would have joined my team had they been a trainee at this firm. So, from my particular point of view I was an NQ, although for all intents and purposes I may as well have been a trainee in my department. So my own feelings of being an NQ were very much not knowing really what was expected of me; not knowing very much about the type of work that I was going to be doing ...

Solicitor, 1 year PQE.

Crucial factors in remedying the deficit apparent for many at the point of qualification were repetition (a quality which would be recognised by the proponents of cognitive theories of expertise development) and the possibility of completing the whole of a transaction (completing an "apprentice piece"). Again, there is potential for a mismatch between the work allocation of the trainee and the work allocation of the newly qualified which can interrupt or even reverse (see the discussion of regression in medical students in Boshuizen et al, 2004, 85ff) the transition towards "full participation".

\section{Conclusions}

The shape of apprenticeship evolves, I suggest, with the profession to which it is attached. The solicitors' profession, challenged by its own regulator as well as by outside entities (the Legal Services Board has now announced a review of legal education: LSB, 2010), is at risk of getting out of step with itself. Some elements of the profession may need to work to catch up and will have hurdles to surmount in finding suitable learning-rich work for their trainees to do, in the face of modern working practices and increased outsourcing of less difficult work to lawyers in other jurisdictions. 
Whether the change to work-based learning, with its set of outcomes that acknowledge some of the activities (administration, billing and business context) that were described by interviewees as new expectations arising on qualification, will assist in reducing the deficit for this profession remains to be seen. It is unlikely, however, that, in the current environment, litigation will ever again provide the small cases or "trainee files" that operated as the apprentice piece of the past. If the apprenticeship regime is not underpinned by attention being given by all supervisors and all employers, to the work allocated to trainees, the profession will be unable to meet such challenges. Even the very limited studies reported in this paper have indicated a range of experiences and responses about work allocation both between and within law firms. It is possible that this is only the tip of an iceberg.

Acknowledgements

My gratitude is due to all interview participants, as well as to my thesis supervisors and examiners, colleagues and to the reviewers of an earlier draft of this article for their helpful comments and suggestions.

Short biographical notes on all contributors

Jane Ching, MA (Cantab); Ph D (NTU), FHEA, solicitor is reader at Nottingham Law School where she specialises in work on the post-academic and vocational stages of the education of legal practitioners. 
References

Benner, P. 1984. From Novice to Expert. Menlo Park, California: AddisonWesley.

Bereiter, C. and Scardamalia, M. 1993. Surpassing Ourselves: An inquiry into the nature and implications of expertise. Chicago: Open Court.

Blasi, G. 1995. What lawyers know: lawyering expertise, cognitive science and the functions of theory. Journal of Legal Education 45(3): 313.

Boon, A. and Webb, J. 2002. Report to the Law Society of England and Wales on The Consultation and Interim Report on the Training Framework Review. London: Law Society.

Boon, A. and Whyte, A. 2002. Legal Education as Vocational Preparation?: Perspectives of Newly Qualified Solicitors. London: University of Westminster.

Boon, A. and Whyte, A. 2007. Looking Back: Analysing Experiences of Legal Experience and Training. The Law Teacher 41(2): 169-190.

Bourdieu, P. 1990. The Logic of Practice. Cambridge, Oxford: Polity Press

Boshuizen, H.P.A., Bromme, R. and Gruber, H. (eds.). 2004. Professional Learning: Gaps and Transitions on the Way from Novice to Expert. Dordrecht: Kluwer Academic Publishers.

Burrage, M. 1996. From a Gentlemen's to a Public Profession: Status and Politics in the history of English Solicitors. International Journal of the Legal Profession. 3(1): 45-80.

Chi, M.T.H., Glaser, R. and Farr, M.J., (eds.). 1988. The Nature of Expertise. Hillsdale, NJ: Lawrence Erlbaum. 
Ching, J. 2009. Research informed support and preparation for achievement of the work-based learning outcomes. Paper presented at the LILAC Conference 2009, Warwick, UK Centre for Legal Education: http://www.ukcle.ac.uk/newsevents/lilac/2009/papers/ching.html

Ching, J. 2009. Young Litigation Solicitors and Their Perceptions Of Movement From Qualification To The 3-Year Watershed. Ph D thesis, Nottingham Trent University.

Clementi, D. 2004. Report of the Review of the Regulatory Framework for Legal Services in England and Wales. London: Department for Constitutional Affairs: $\quad$ http://www.legal-servicesreview.org.uk/content/report/index.htm

Colley, H., James, D., Tedder, M. and Diment, K. 2003. Learning as Becoming in Vocation Education and Training: class, gender and the role of vocational habitus. Journal of Vocational Education and Training 55(4): 471.

Department For Constitutional Affairs. 2005. The Future of Legal Services: Putting Consumers First. Cm 6679, Norwich: HMSO.

Dreyfus, H.L. and Dreyfus, S.E. 1986. Mind over Machine. New York: The Free Press.

Engestrom. Y. 2007. From Communities of Practice to Mycorrhizae. In Communities of Practice, Critical Perspectives. Ed. J. Hughes, N. Jewson and L. Unwin. London: Routledge. 41-54.

Eraut, M. 2004. Deconstructing Apprenticeship Learning: what factors affect its Quality? In New Approaches to Vocational Education in Europe, ed. R. H. Mulder and P. F. E. Sloane. 45-57. 
Eraut M. and Furner, J. 2002. Learning during the first three years of postgraduate employment - the LiNEA Project: Interim Report for Accountancy. TLRP: ESRC.

Eraut M. undated. End of Award Report: Learning During the First Three Years of Postgraduate Employment. TLRP: ESRC

Evetts, J. 2006. The Sociology of Professional Groups: New Directions. Current Sociology 54 133-143

Evetts, J. 2006. Trust and Professionalism: Challenges and Occupational Changes. Current Sociology 54 515-531.

Fancourt, A. 2004. Hitting the ground running? Does the Legal Practice Course prepare students adequately for the training contract? Warwick, UK Centre for Legal Education. http://www.ukcle.ac.uk/research/ukcle/fancourt.html

Farrar, J. August 2001. Arrogant, incompetent, negligent and unprofessional ... Which? 8-11.

Faulconbridge, J. and Muzio, D. 2008. Organizational Professionalism In Globalizing Law Firms. Work, Employment and Society. 22(7) 7-25.

Fournier, V. 1999. The Appeal to "Professionalism" as a disciplinary mechanism. Sociological Review 280-307.

Fuller, A. and Unwin, L. 2003. Fostering Workplace Learning: Looking Through The Lens Of Apprenticeship. European Educational Research Journal. 2(1) 41-55

Fuller, A. and Unwin, L. 2003. Learning As Apprentices In The Contemporary UK Workplace: Creating And Managing Expansive And Restrictive Participation. Journal of Education and Work. 16(4): 407-426.

Fuller, A. and Unwin, L. 2009. Change And Continuity In Apprenticeship: The 
Resilience Of A Model Of Learning. Journal of Education and Work. 22(5): 405-416.

Fuller.A. 2007. Critiquing Theories of Learning and Communities of Practice. In Communities of Practice, Critical Perspectives. Ed. J. Hughes, N. Jewson and L. Unwin. London: Routledge. 17-29.

Galanter, M and Roberts, S. 2008. From Kinship to Magic Circle: the London Commercial Law Firm in the Twentieth Century. International Journal of the Legal Profession. 15(3):143-178.

Hughes. J. Lost in Translation: communities of practice - the journey from academic model to practitioner tool. In Communities of Practice, Critical Perspectives. Ed. J. Hughes, N. Jewson and L. Unwin. London: Routledge.30-40.

Hunt, D. (Lord Hunt of Wirral). 2009. The Hunt Review of the Regulation of Legal Services. London: Law Society.

Kelly, A. 2001. "Too Busy To Think, Too Tired To Learn" - The Attrition Of The Apprenticeship Model Of Surgical Training In The United Kingdom. Educate. 1(1) 45-65.

Kitchener, K.S. and King, P.M. The reflective judgment model: Transforming assumptions about knowing. 1990. in Mezirow, J. and associates. Fostering Critical Reflection in Adulthood. San Francisco: Jossey Bass.

Larson, M. S. 1977. The Rise of Professionalism: a Sociological Analysis. Berkley: University of California Press.

Laurence Simons. 2010. Educated the Expensive Way: Legal Profession's Elitism Gap Widens. London: Laurence Simons International Legal Recruitment. http://www.laurencesimons.com/educated-the-expensive-way 
Lave, J. and Wenger, E. 1991. Situated Learning: Legitimate Peripheral Participation. Cambridge: Cambridge University Press.

Law Society of England And Wales. 2001. Training Framework Review Consultation Paper. London: Law Society.

Law Society of England And Wales. 2003. Second Consultation Paper on a New Training Framework for Solicitors. London: Law Society.

Law Society of England And Wales. 2005. Qualifying as a Solicitor - a framework for the future, a consultation paper. London: Law Society.

Law Society of England And Wales. 2009. Trends in the Solicitors' Profession: Annual Statistical Report 2009. London: Law Society.

Legal Services Board. 10 November 2010. Review Of Training For Lawyers In England And Wales. London, Legal Services Board $\underline{\text { http://www.legalservicesboard.org.uk/news publications/press releases/pdf/ }}$ $201011 \quad 18$ upjohn.pdf (accessed 23 November 2010)

Lingard, L, Garwood, K., Schryer, C. F. and Spafford, M. 2003. A Certain Art Of Uncertainty: Case Presentation And The Development Of Professional Identity. Social Science and Medicine. 56: 603-616.

Maillardet, F., Ali, A. and Steadman, S. 2002. Learning during the first three years of postgraduate employment - the LiNEA Project: Interim Report for Engineering. TLRP: ESRC.

Marshall, J. 2004. A Shift to a Post-Structuralist Analysis of the Legal Profession. International Journal of the Legal Profession. 11 (1\&2) 21-31.

Miller, C. and Blackman, C. 2002. Learning during the first three years of postgraduate employment - the LiNEA Project: Interim Report for Nursing. TLRP: ESRC. 
Monahan, M.A. 2001. Towards a theory of assimilating law students into the culture of the legal profession. Catholic University Law Review 51: 215.

Neumann, R.K. jr. Spring 2000. Donald Schön, the reflective practitioner and the comparative failures of legal education. Clinical Law Review 6: 401.

Rogers, A. 2003. What is the Difference? A new Critique of Adult Learning and Teaching. Leicester: NIACE.

Sanderson, P. and Sommerlad, H. 2002. Exploring the Limits to the Standardization of the Expert Knowledge of Lawyers: Quality and Legal Aid Reforms in the United Kingdom. Syracuse Law Review 52: 987.

Schön, D.A. 1983. The Reflective Practitioner. Aldershot: Ashgate, Arena.

Schön, D.A. 1987. Educating the Reflective Practitioner. San Francisco: JosseyBass.

Schön, D.A. Fall 1995. Educating the Reflective Legal Practitioner. Clinical Law Review 2: 231.

Sherr, A. 2001. Professional Work, Professional Careers and Legal Education: Educating the Lawyer for 2010. London: Institute of Advanced Legal Studies. http://ials. sas.ac.uk/research/woolf/lawyer2010.htm.

Solicitors Regulation Authority. November 2000. Training Regulations 1990. London: Solicitors' Regulation Authority.

Solicitors Regulation Authority. February 2007. Education, Training and Development for Solicitors: The Way Ahead. London: Solicitors' Regulation Authority.

Solicitors Regulation Authority. 2008. Training Trainee Solicitors; The Solicitors Regulation Authority Requirements. London: Solicitors' Regulation Authority. 
Solicitors Regulation Authority. 2008. Work Based Learning Pilot: Handbook for all Participants. London: Solicitors' Regulation Authority.

Sommerlad, H. 2007. Researching and Theorizing the Processes of Professional Identity Formation. Journal of Law and Society 34(2): 190.

Sommerlad, H. 2008. "What are you doing here? You should be working in a hair salon or something": outsider status and professional socialization in the solicitors' profession. Web Journal of Current Legal Issues, 2.

Tennant, M. 1997. Psychology and Adult Learning, (2 $2^{\text {nd }}$ ed.). London: Routledge.

Vignaendra, S. 2001. Social Class and Entry into the Solicitors' Profession. London: Law Society. 